\title{
Towards Upgrading Strategies for nZEB-Dwellings in Norway
}

\section{Lars Gullbrekken*, Berit Time}

SINTEF Building and Infrastructure, Trondheim, Norway

*Corresponding author: lars.gullbrekken@sintef.no

「ross

Recent work suggests that upgrading in line with the Norwegian building regulations or by upgrading to the requirements of the national passive house norm, NS3700, can enable nZEB level to be achieved. The aim of this work is to explore the typical Norwegian housing typologies and some important characteristics of the building envelope for these houses from different decades. The exploration involved surveying the typical technical qualities of Norwegian housing and how these have evolved - providing an important foundation to work addressing strategies and methods for upgrading dwellings to nZEB level in the next phases of the ongoing research project. The results of this work show that the building norms and practices developed throughout the years have made dwellings more moisture resilient, with an increased drying-out potential through mechanical ventilation, control of the air change rate and the use of more vapour-open wind barriers in the building envelope. Based on this, the work to follow will suggest strategies for upgrading to nZEB level, solutions for upgrading building envelope components to high performance level and a methodology for risk reduction of moisture problems in the upgraded dwellings from the different decades.

Keywords: Building physics; Moisture resilience; Energy upgrading of buildings; nZEB; Dwellings.

\section{Norwegian tradition of wooden houses}

Norwegian residential buildings are largely detached wooden houses, $60 \%$ of which are detached houses built between 1960 and 1990 and are by now 30-60 years old. (Sentralbyrå., 2010.) This building stock is now rapidly reaching a stage where major renovations need to take place. The annual number of new dwelling units passed 40,000 in the period from 1970 to 1975. In comparison, the dwelling stock increased by 32,000 in 2017 (SSB, 2018). The large number of completed detached houses in the 1960s, 1970s and 1980s, together with strict rules from the Norwegian Housing Bank for obtaining mortgages, have led to the building typology of this period being quite homogeneous (see Fig. 1). The population of detached houses often consist of a concrete or masonry basement. Further, the houses have a wood-frame exterior wall construction with mineral wool insulation, and a wooden exterior cladding. The building envelope and technical system are less energy efficient than similar houses of today and hence, a potential for energy saving renovation exists (Risholt, 2013). Some examples of the development of the prefabricated houses are given in Table 1.

\section{Introduction}

Towards Upgrading Strategies for nZEBDwellings in Norway

Received 2018/11/15

Accepted after revision 2019/05/02

(1)

.


Fig. 1

Dwellings units completed in the period from 1951 to 1993. The results are sorted by type of house: One-family houses, divided small houses and large houses. (Myhre, 1995)

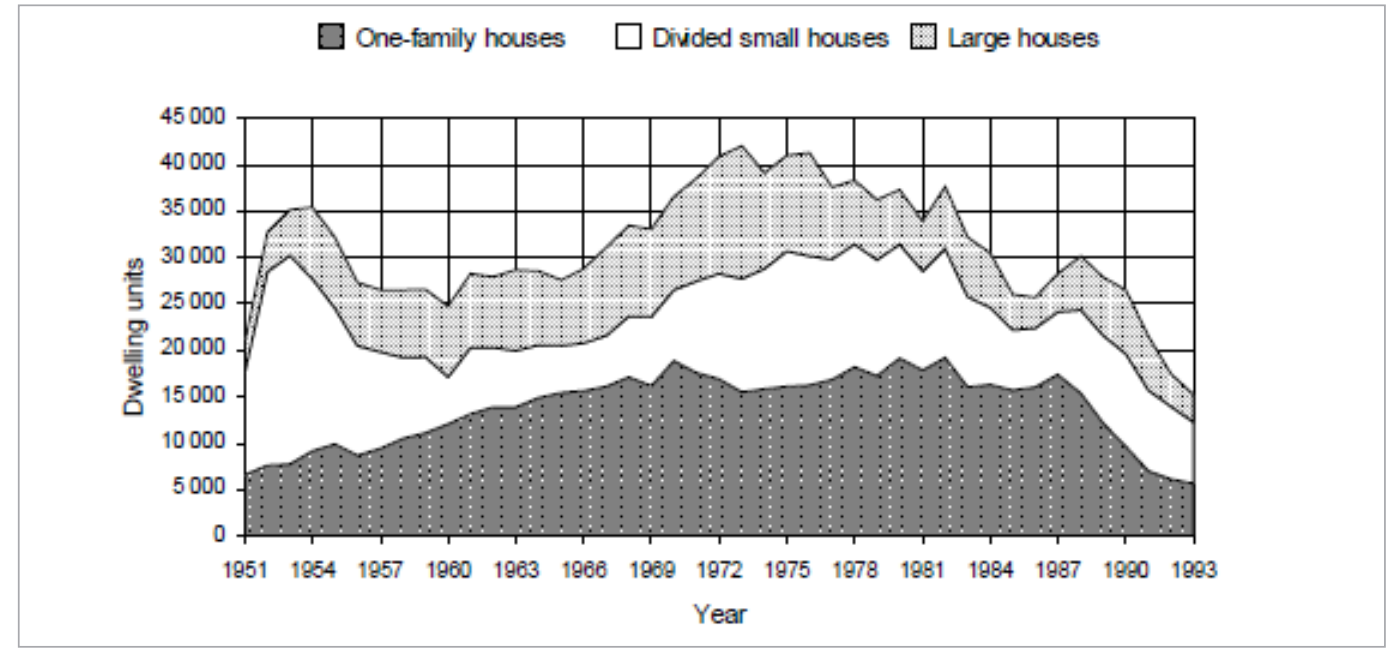

\section{Table 1}

Typical examples of the development of prefabricated houses from 1950 to 1990 (Støa, 2018)

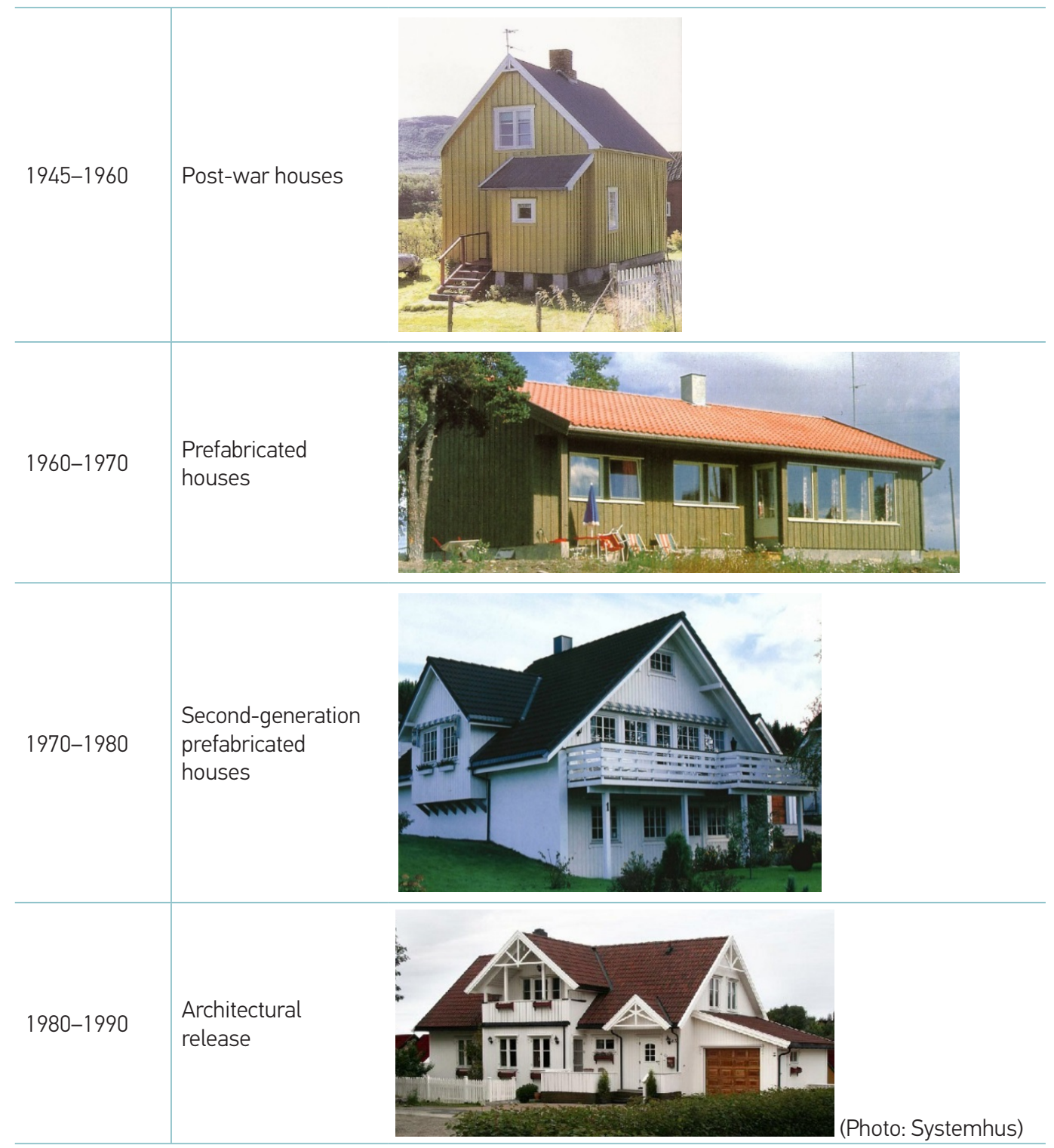




\section{Towards nZEB upgrading}

Actions to reduce the greenhouse gas emissions from buildings are important, since buildings account for $10 \%$ of global $\mathrm{CO}_{2}$ emissions (Agency, 2010). According to the The European Union Directive 2010/31 (Council, 2010) and Norwegian government (KMD, 2017), all new buildings should be built according to nZEB level by 2020. . Risholt (2013) has demonstrated that this is possible also for upgrading of dwellings, in theory, and Lien et al. (2017) in practise.

To save energy in the building sector, it is necessary to increase the focus on upgrading of the existing building stock. According to Risholt (2013), the energy use of Norwegian single-family houses was 30 TWh in 2009. By upgrading the building envelope of detached houses built before 1990, a potential energy saving of 8 TWh was found.

Risholt (2013) studied the possibility of renovating a Norwegian single-family house to become a zero energy building (ZEB) while at the same time meeting cost and quality requirements. She focused on single-family houses built in the 1980s and found that Norwegians spend huge sums of money on the upgrading of kitchens and bathrooms. Some of the houses were already renovated; however, no correlation was found between the number of building defects and the renovation status. Two possible strategies for renovating to zero energy standards were identified. The first option was the façade solution, which included upgrading the thermal properties of walls, windows and doors as well as installation of balanced ventilation and renewable energy production on site (e.g BIPV). The second option was a more ambitious strategy, which included upgrading of the building envelope to passive house level, installation of ventilation and renewable energy production on site (e.g BIPV).

The renovation of most wooden dwellings aims for energy levels that are similar to the original standard; this often happens because of poor energy advice(Risholt, 2013). Only half of the renovations taking place in Norway include energy renovation. (Risholt, 2013)( Bjørnstad 2015). Building components have a service life of 30-50 years and are typically only replaced when needed, we therefore may risk "energy lock-in" if, for example, the cladding is replaced without adding insulation at the same time, or if the roofing is replaced without extending the overhang and preparing for additional wall insulation. Along with energy advises we also experience a need for generic moisture safety advises. In upgrading projects, insulation on the exterior face of the construction often creates typical questions like: "What is required on the internal side of the construction?" or "Is the airtightness and the vapour resistance of the existing vapour barrier and internal layers high enough to avoid problems?" Today there exist no tools that can give a straight answer to this question without assessing the construction in each individual case. Some relevant information exists, but the information is scattered and several sources have to be used.

\section{Aim of work}

The aim of this work has been to explore the typical Norwegian housing typologies and some important characteristics of the building envelope for housing from the different decades studied. The exploration involved the surveying of the typical technical qualities of Norwegian housing, looking into how these have evolved over the years. This forms an important foundation to work addressing strategies and methods for upgrading dwellings to nZEB level in the next phases of the ongoing research project.

This study is conducted primarily as a literature and document study.

Norwegian building rules ${ }^{1}$ from the last 60 years have been used, as has the Norwegian knowledge system Byggforskserien (The Building Research Design Sheets) and Trehusboka (The Nor-

\footnotetext{
${ }^{1}$ Norwegian building rules from 1965-2017 available from: https://www.regjeringen.no/no/tema/plan-bygg-og-eiendom/ bygningsregelverket-fra-1965--20172/bygningsloven/id2590707/
} 
wegian Wooden House Book). Norwegian technical approvals for building products over the last 30 years have also been used. A technical approval indicates that a construction product is considered to be suitable for use and meets the requirements of the building regulations for the uses and conditions specified in the approval document.

Trehusboka (Granum H, Lundby SE, 1952) is a reference series for wooden houses in Norway and was first published in 1952. The following versions of Trehusboka have been reviewed and applied this work: 1952, 1958, 1961, 1965, 1970, 1980, 1990, 1997, 2007. The book has been in line with practise throughout the years and the continuous update of Trehusboka makes it a unique reference series.

Byggforskserien ${ }^{2}$ is a series of documented solutions for those who build, run projects and manage buildings in Norway. Byggforskserien has co-existed with the Norwegian building rules and building practises for 60 years and is the most widely used system for building engineering solutions in Norway. The solutions in Byggforskserien have always been better than, or according to, the building regulations. Instructions in Byggforskserien therefore show and document the development of regulations and technical solutions and are a unique source for studying (the technical) development of Norwegian housing models.

The study is limited to Norwegian dwellings, but it is likely that the study and findings herein will have a great transfer value to other countries with a long history of wooden houses.

\section{Building regulations development for thermal insulation}

According to Myhre (1995), the main purpose of the Norwegian building regulations of 1949 was to provide a satisfactory indoor climate. The requirements of 1965 barely even involved updating the thermal insulation level to that already commonly practised in construction (Granum, 1989). However, the thermal insulation level requirements were tightened in 1985. During the 1980s it was common to construct walls with $150 \mathrm{~mm}$ thick insulation and roofs with $200 \mathrm{~mm}$ thick insulation. Windows with low emission layers gained market share during the same period (Granum, 1990), as shown in Table 2. Table 3 shows how the insulation levels recommended by the Norwegian Building Research Institute have steadily increased in the period from 1952 to today.

Table 2

Technical minimum demands for energy performance/thermal insulation given for building envelope parts according to the Norwegian building regulations throughout the studied years. TEK97 means 1997 and so on

\begin{tabular}{|c|c|c|c|c|c|c|c|c|c|}
\hline \multirow{2}{*}{ Building part } & & \multirow{2}{*}{1949} & \multirow{2}{*}{1965} & \multirow{2}{*}{1985} & \multirow[b]{2}{*}{1987} & \multirow{2}{*}{ TEK97 } & \multirow{2}{*}{$\begin{array}{c}\text { TEK07 } \\
*\end{array}$} & \multicolumn{2}{|c|}{ TEK10/TEK17 } \\
\hline & & & & & & & & * & ** \\
\hline Wall & {$\left[\mathrm{W} / \mathrm{m}^{2} \mathrm{~K}\right]$} & $\begin{array}{c}0.70- \\
1.05\end{array}$ & $\begin{array}{c}0.46- \\
0.58\end{array}$ & 0.35 & 0.30 & 0.22 & 0.18 & 0.18 & 0.22 \\
\hline Window & {$\left[\mathrm{W} / \mathrm{m}^{2} \mathrm{~K}\right]$} & & & 2.7 & 2.4 & 1.6 & 1.2 & 0.80 & 1.2 \\
\hline Door & {$\left[\mathrm{W} / \mathrm{m}^{2} \mathrm{~K}\right]$} & & & 2.0 & 2.0 & 1.6 & 1.2 & 0.80 & 1.2 \\
\hline Roof & {$\left[\mathrm{W} / \mathrm{m}^{2} \mathrm{~K}\right]$} & $\begin{array}{c}0.70- \\
1.05\end{array}$ & $\begin{array}{c}0.41- \\
0.46\end{array}$ & 0.23 & 0.20 & 0.15 & 0.13 & 0.13 & 0.18 \\
\hline Basement walls & {$\left[\mathrm{W} / \mathrm{m}^{2} \mathrm{~K}\right]$} & $\begin{array}{c}1.16- \\
1.86\end{array}$ & $\begin{array}{l}1.57- \\
2.33\end{array}$ & 0.8 & 0.8 & 0.22 & 0.18 & 0.18 & 0.22 \\
\hline $\begin{array}{l}\text { Floor towards external } \\
\text { air }\end{array}$ & {$\left[\mathrm{W} / \mathrm{m}^{2} \mathrm{~K}\right]$} & & $\begin{array}{c}0.41- \\
0.46\end{array}$ & 0.23 & 0.20 & 0.15 & 0.15 & 0.10 & 0.18 \\
\hline Slab on ground & {$\left[\mathrm{W} / \mathrm{m}^{2} \mathrm{~K}\right]$} & & & 0.3 & 0.30 & 0.15 & 0.15 & 0.10 & 0.18 \\
\hline Window area & $\begin{array}{l}{\left[\mathrm{m}^{2} /\right.} \\
\mathrm{m}^{2} \text { heated area] }\end{array}$ & & & 0.15 & 0.2 & 0.2 & 0.2 & 0.25 & 0.25 \\
\hline Air change rate, $n_{50}$ & {$[1 / \mathrm{h}]$ at $50 \mathrm{~Pa}$} & & & 4 & 4 & 4 & 2.5 & 0.6 & 1.5 \\
\hline
\end{tabular}

*Energy measures method.

${ }^{* *}$ Minimum requirements for the building part, which imply stricter requirements for other building parts to fulfil the overall energy norm.

\footnotetext{
${ }^{2}$ Byggforskserien available at https://www.byggforsk.no/
} 


\begin{tabular}{l|l|c|c|c|c}
\hline \multicolumn{1}{c|}{ Building part } & & $1950-1970$ & $1970-1980$ & $1980-1990$ & $1990-2000$ \\
\hline Wall & {$\left[\mathrm{W} / \mathrm{m}^{2} \mathrm{~K}\right]$} & 0.30 & 0.30 & 0.30 & 0.18 \\
\hline Window & {$\left[\mathrm{W} / \mathrm{m}^{2} \mathrm{~K}\right]$} & & & 2.4 & 1.2 \\
\hline Door & {$\left[\mathrm{W} / \mathrm{m}^{2} \mathrm{~K}\right]$} & & & 2.4 & 1.2 \\
\hline Roof & {$\left[\mathrm{W} / \mathrm{m}^{2} \mathrm{~K}\right]$} & 0.30 & 0.30 & 0.23 & 0.15 \\
\hline Floor towards external air & {$\left[\mathrm{W} / \mathrm{m}^{2} \mathrm{~K}\right]$} & 0.30 & 0.30 & 0.23 & 0.15 \\
\hline Slab on ground & {$\left[\mathrm{W} / \mathrm{m}^{2} \mathrm{~K}\right]$} & & & 0.30 & 0.15 \\
\hline Window area & {$\left[\mathrm{m}^{2} / \mathrm{m}^{2}\right]$} & & & 0.15 & 0.20 \\
\hline Air change rate $($ at $50 \mathrm{~Pa})$ & {$[1 / \mathrm{h}]$} & & & & 4 \\
\hline
\end{tabular}

Table 3

Recommendations given in Byggforskserien regarding technical demands energy performance/ thermal insulation for building envelope parts throughout the studied years. Empty cells mean no distinct recommendations

From the beginning of the 1950s it was considered profitable to use mineral wool insulation in roof and wall constructions instead of the old materials such as clay and sawdust (Granum and Lundby, 1952). By the end of the 1950s, most houses were constructed with mineral wool insulation in the outer constructions (Myhre, 1995). The thermal conductivity of the mineral wool has been lowered from $0.041 \mathrm{~W} / \mathrm{mK}$ in 1958 down to today's value of $0.031-0.034 \mathrm{~W} / \mathrm{mK}$.

\section{Vapour- and wind barrier moisture characteristics}

A moisture-safe wood-frame construction assumes a low vapour and air permeability on the internal, warm face of the construction and a high vapour permeability on the external, cold face of the construction (Thue et al., 1996; Vinha, 2007). Based on laboratory measurements on insulated wood-frame walls with different insulation materials and different vapour barrier vapour permeabilities, Thue et al. (1996) recommend the use of PE-foil as a vapour barrier. Further, a ratio between the diffusion resistances of the wind barrier and the vapour barrier larger than ten was recommended in order to avoid interstitial condensation problems. In addition, a moisture-safe construction assumes a vapour-open wind barrier in order to dry out excessive moisture. Table 4 shows the vapour diffusion resistance of the typical materials/product categories used for windand vapour barriers in the period 1960-2007. For some of the values a span in reported. In these cases the vapour diffusion resistance is varying with the thickness of the material.

\begin{tabular}{l|c|c|c|c|c}
\hline Material & 1960 & 1970 & 1980 & 1990 & 2007 \\
\hline $\begin{array}{l}\text { Recommendation } \\
\text { vapour barrier }\end{array}$ & $>10 \mathrm{~m}$ & $>10 \mathrm{~m}$ & $>10 \mathrm{~m}$ & $>10 \mathrm{~m}$ & $>10 \mathrm{~m}$ \\
\hline Plastic-coated cardboard & $50 \mathrm{~m}$ & $10-15 \mathrm{~m}$ & & & \\
\hline Plastic foil, polyethylene & & $15-30 \mathrm{~m}$ & $25-100 \mathrm{~m}$ & $70-100 \mathrm{~m}$ & $70-100 \mathrm{~m}$ \\
\hline Asphalt-coated cardboard & $15 \mathrm{~m}$ & $15 \mathrm{~m}$ & $20 \mathrm{~m}$ & & \\
\hline $\begin{array}{l}\text { Recommendation } \\
\text { wind barrier }\end{array}$ & $<1.9 \mathrm{~m}$ & $<1.9 \mathrm{~m}$ & $<1.9 \mathrm{~m}$ & $<1.7 \mathrm{~m}$ & $<0.5 \mathrm{~m}$ \\
\hline $\begin{array}{l}\text { Impregnated fibre boards } \\
\text { Gypsum board 13 mm }\end{array}$ & & $0.1-0.4 \mathrm{~m}$ & $0.1-0.4 \mathrm{~m}$ & $0.2-0.3 \mathrm{~m}$ & $0.2-0.3 \mathrm{~m}$ \\
\hline Wind barrier foils & & $<0.1 \mathrm{~m}$ & $<0.1 \mathrm{~m}$ & $0.1-0.15 \mathrm{~m}$ & $<0.1 \mathrm{~m}$ \\
\hline
\end{tabular}

\section{Table 4}

Vapour diffusion resistances (sd-values) for typical materials/ product categories used for vapour- and wind barriers in the period from 1960 to 2007. Cited from Byggforskserien, Trehusboka and Technical Approvals. Empty cells means that no value has been found in the references

\section{Discussion}

Since 1950, there have been increasingly strict building regulations concerning the technical demands for building parts. In recent decades the revisions have been more frequent but the minimum demands for heat insulation of building parts have, to a large extent, been constant since 
1987. However, during this period, the requirement for the air change rate of the building envelope has been lowered from 4 to $1.5 \mathrm{~h}^{-1}$ (at 50 Pa pressure difference). The requirement for high-performance heat recovery of the ventilation air was added in 2010 , requiring balanced ventilation (an improved mechanical ventilation system where both the air inlet and outlet are controlled by fans). The frequent revisions during the 2010s can be explained by an increased focus on energy use in buildings - by the Norwegian government in particular. During this period, the Norwegian passive house standard was developed and was first published in 2010 (NS3700, 2010).

\section{Ventilation strategies throughout the years}

Heat loss from infiltration and ventilation represented about one-third of the total heat loss from a typical detached one-family houses built before 1990 (Granum, 1990). As Table 2 shows, no requirements for air infiltration through the building envelope were given before 1987. Air leaks in the outer part of the construction are referred to as infiltration. The infiltration rate varies by local wind conditions, type of building, type of construction and craftmanship. Natural ventilation strategies, where the air exchange is driven by thermal buoyancy, were common in small houses up to about 1980. From 1980 it was more common to install mechanical ventilation systems in new dwellings. These systems have fans, which drag air out of the building, providing steadier ventilation rates compared to natural ventilation systems (Myhre, 1995). During the late 1990s and early 2000s, it became increasingly common to install balanced ventilation systems, even in small houses. A heat recovery unit makes it possible to utilise the energy content of the outlet air. As a result of increasingly strict demands for building infiltration during the 2010s, the focus on infiltration through the building envelope has increased. According to TEK 17 (2018), the maximum limit of air infiltration is set to 1.5 air changes per hour at 50 Pa pressure difference. The increasing focus on building infiltration has led to a positive focus on air tightening, especially air tightening of the wind barrier. An airtight wind barrier is, together with an airtight vapour barrier, not only a measure to save energy, but also a measure to avoid building defects caused by, for example, convection of warm, humid indoor air through the structure (Langmans et al., 2010; Gullbrekken et al., 2016).

\section{Development of building products}

According to the early editions of Trehusboka from 1952 and through the decades that followed, different types of cardboard were used both for the vapour and wind barrier. Plastic-coated cardboard was used as a vapour barrier and asphalt-coated cardboard was used as a wind barrier. Concerning vapour diffusion resistances for vapour barriers, the recommendations in the different editions of Trehusboka and Byggforskserien have been constant from 1950 to today. The recommendations concerning vapour diffusion resistances for the wind barrier were constant from 1950 to 2007. In 2007 the recommendations were lowered to one-quarter of the existing demands. Findings in the studies of (Thue et al., 1996; Vinha, 2007), as well as the increased typical wall insulation thickness (from $150 \mathrm{~mm}$ to $200 \mathrm{~mm}$ ), implied a need for larger dry-out capacity due to the increased amount of wood and hence an increased possibility of built-in moisture. New building products were introduced, including large-format wind barrier foils which entered the Norwegian market during the 1990ies. These new products had a higher water vapour permeability (e.g Sd-values from 0,02-0,06 m) compared to the traditional wind barriers and the use of large-format rolls made it easier to achieve high air-resistance performance.

\section{Measures - moisture safety and energy performance}

An nZEB upgrading of a dwelling implies a need to focus on additional insulation on the exterior or interior face of the existing construction and the overall consequences of this. The upgrading measures can often be performed in different steps. In order to secure high architectural and technical performance, joints between the different building parts have to be planned. One typical practical example is that additional exterior wall insulation affects the roof overhang of the specific 
building and should be accounted for when the roof is upgraded. In addition to lowering energy consumption, the addition of insulation in different building parts is increasing the moisture mould growth potential of these constructions in general (Gullbrekken et al., 2015). However, by replacing the existing wind barrier with a modern product (vapour open foil), the vapour resistance of the wind barrier is lowered and the dry-out potential of the construction increases. In addition, these modern wind barriers often imply a lower air permeability of the construction, which increases the moisture robustness (Relander, 2011). Installation of balanced ventilation is lowering the humidity level of the internal air and hence further increasing the moisture robustness of the construction. Such actions are of great importance both for the builders and the owners.

A risk assessment tool based on fault tree analysis could be applied and a way forward, considering the moisture safety of the existing and upgraded solution to make it easier to get a simplified overview of the situation and to make correct choices for different constructions. The general method is described in IEC 61025 (2006). Previously, (Arfvidsson et al., 2016) presented a method for risk analysis of energy upgrading of historical buildings. The method included measurements and assessments of each specific building. In order to give practical advice to the building industry, a more general assessment method is needed, one that focuses on energy upgrading of small Norwegian houses built in the period 1950-1990. A considerable proportion of detached houses from the 1960s and 1970s have already been upgraded to some extent - the implications of this must be included in the risk assessment tool.

In order for a building to reach nZEB level, the heat loss through the building envelope needs to be relatively small, and the building likely needs to be equipped with energy producing products. The nZEB level is still being debated internationally and is not yet defined. The research project of which this work is a part, is aiming at making a definition of nZEN level for upgrading of dwelling. Anyhow, the energy consumption and production must be documented. However, there is a question of how much extra insulation the different building parts need. According to the study of Risholt (2013), façade improvements have higher impact on the heat loss than improvements to other building parts. This is confirmed in the study of Skeie et al. (2014) and is mainly explained by improved airtightness and hence lowered infiltration loss (Skeie et al., 2014). According to Skeie et al. (2014), improvement of the U-value of windows or reduction of the window area, is the single building envelope improvement measure that has the largest energy saving potential. Further, a description of a three-step upgrading of the building envelope of existing detached houses from the 1960s, 1970s and 1980s is presented in Lien et al. (2017). This three-step method includes the upgrading of the roof construction, exterior wall construction and floor construction. The study of Lien et al. 2017 includes upgrading up to the current Norwegian building regulations (TEK17) and to the Norwegian passive house requirements (NS3700). However, upgrading to TEK17 level requires installation of more renewable energy production compared to the NS3700 level in order to fully balance the energy consumption.

Previous work suggests that upgrading to nZEB level can be reached by upgrading in line with the Norwegian building regulation or by upgrading to the requirements of NS3700. However, dependent on the definition of nZEB, upgrading to the current building regulations requires installation of renewable energy production on the dwelling in order to fully balance the energy consumption (Zero Energy Building level). The results of this work show that building norms and practices throughout the years have made dwellings more moisture resilient, with an increased drying-out potential through mechanical ventilation, control of the air change rate and more vapour-open wind barriers in the building envelope. Based on this survey, the work to follow will suggest strategies for upgrading to nZEB level, solutions for upgrading building envelope components to high performance level and a methodology for risk reduction of moisture problems in the upgraded dwellings from the different decades. 


\section{Acknowledgements}

This paper has been written within the Research Project "Energy upgrading of wooden dwellings to nearly zero energy level" (OPPTRE). The authors gratefully acknowledge the support from the OPPTRE partners and the Research Council of Norway.

\section{References}

Agency IE. (2010) Energy technology perspectives 2010: scenarios and strategies to 2050. In: Paris Ol (ed). Arfvidsson J, Bjerke-Holtermann B and Mattson J. (2016) Metoder for riskbedomning av historiska byggnader. Bygg \& Teknik. 6: 12-16

Council (2010) Directive 2010/31/EU of The European Parliament and the Council of 19.05.10 on the energy performance of buildings. Off. Journal of the European Union.

Granum H, Lundby SE. (1952) Trehus i dag. Anvisning nr. 1, Norges Teknisk Naturvitenskapelige Forskningsråd, Oslo, Norway, (in Norwegian).

Granum H. (1989) Memorandum. Trondheim, Norway, 1989 (in Norwegian).

Granum H. (1990) Bygningers varmeisolering i dag og sannsynlig utvikling. NIF Studiesenteret, Trondheim, Norway, 1990 (in Norwegian).

Gullbrekken L, Geving S, et al. (2015) Moisture conditions in well-insulated wood-frame walls. Simulations, laboratory measurements and field measurements. Wood Material Science \& Engineering 10: 232-244. https://doi.org/10.1080/17480272.20 15.1064473

Gullbrekken L, Kvande T. et al. (2016) Norwegian Pitched Roof Defects. Buildings 6: 24. https://doi. org/10.3390/buildings6020024

IEC 61025 (2006) Fault tree analysis (FTA) International Electrotechnical Commission.

Langmans J, Klein R, et al. (2010) Potential of wind barriers to assure airtightness of wood-frame low energy constructions. Energy and Buildings 42: 2376-2385. https://doi.org/10.1016/j.enbuild.2010.08.021

Lien AG, Skeie KS, et al. (2017) Oppgradering av et 60-tallshus og et 70-tallshus. (In Norwegian) SINTEF
Fag 42. SINTEF Building and Infrastructure. Norway. Myhre L. (1995) Some environmental and economic aspects of energy saving measures in houses. PhD-thesis. Building and construction technology. NTH, 1995:120.

NS3700 (2010) Criteria for passive houses and low energy buildings - Residential buildings. Standard Norge.

Relander TO. (2011) Airtightness of wood-frame houses. PhD-thesis. NTNU, 2011:331.

Risholt B. (2013) Zero energy renovation of single family houses. PhD-thesis. Department of Architecture and Design. NTNU, 2013:153.

Sentralbyrå S. (2010) Boligarealstatistikk 2009 [Dwelling area statistics 2009].

Skeie K, Kleiven T, et al. (2014) Energiplan- tre trinn for tre epoker. SINTEF Fag 25. SINTEF Building and Infrastructure, 55.

SSB (2018) Statistics Norway - Greatest increase in 12 years. Visited 05.11.2018 https://www.ssb.no/ bygg-bolig-og-eiendom/artikler-og-publikasjoner/storste-boligvekst-pa-tolv-ar

Støa E. (2018) Presentation in the research project OPPTRE. 03.09.2018. Trondheim.

TEK17 (2018) Forskrift om tekniske krav til byggverk (in Norwegian). Lovdata. Visited 06.11. 2018 https:// lovdata.no/dokument/SF/forskrift/2017-06-19-840

Thue JV, Skogstad HB, et al. (1996) Wood Frame Walls in Cold Climate - Vapour Barrier Requirements. Journal of thermal insulation and building envelopes 20: 63-75. https://doi. org/10.1177/109719639602000106

Vinha J. (2007) Hygrothermal performance of timber-framed external walls in Finnish climatic conditions: A method for determining the sufficient water vapour resistance of the interior lining of a wall assembly. PhD-thesis. Tampere University of Technology.

\section{About the} Authors

\section{LARS GULLBREKKEN}

$\mathrm{PhD}$, Researcher

SINTEF Building and Infrastructure

Main research area

Building Physics

\section{Address}

Høgskoleringen 7B

7046 Trondheim

\section{BERIT TIME}

$\mathrm{PhD}$, Chief Scientist

SINTEF Building and Infrastructure

\section{Main research area}

Building Physics

Climate adaptation

\section{Address}

Høgskoleringen 7B

7046 Trondheim 